\title{
Chinese Cotton Mill Owner's Association and the Construction of Information System of China's Cotton Industry
}

\author{
Huaming Zhang ${ }^{1} \&$ Dawei Liao ${ }^{1}$ \\ ${ }^{1}$ College of Humanities, Donghua University, Songjiang, Shanghai, China \\ Correspondence: Dawei Liao, College of Humanities, Donghua University, Songjiang, Shanghai, 201620, China. \\ E-mail: liaodawei1961@163.com
}

Received: June 24, 2020

Accepted: July 1, $2020 \quad$ Online Published: July 22, 2020

doi:10.5539/ass.v16n8p78

URL: https://doi.org/10.5539/ass.v16n8p78

Foundation item: Innovation project for Ph.D. candidate of Donghua University "The arrangement and research of modern Chinese textile history materials" stage of achievements.

\begin{abstract}
The Federation of Chinese Cotton Mill Owner's Association is a very important national cotton textile industry group in modern Chinese history, which has had an important impact on the development of modern China's cotton industry in many aspects. Especially in the construction of information system of cotton textile industry, the Chinese Federation of cotton mills is the first industry organization to put forward ideas and put them into practice, which has made great contribution to the communication and exchange of modern technology and management of cotton textile industry. The Federation of Chinese Cotton Mill Owner's Association not only established the information construction of cotton industry at its institutional level, but also paid close attention to the information of American cotton market closely related to modern China's cotton textile industry. This paper will study and discuss the role of the Federation of Chinese Cotton Mill Owner's Association in the establishment of China's cotton information system, in order to clarify the important role of the Federation in the construction of modern China's cotton information system.
\end{abstract}

Keywords: Chinese Cotton Mill Owner's Association, Cotton industry in modern China, Information system

Since modern times, China's largest national industry is cotton textile industry. In the economic development history of modern China, the national cotton textile industry occupies a very important position. Founded in Shanghai in the early Republic of China, Chinese Cotton Mill Owner's Association is a national industrial organization of modern Chinese national cotton textile industry and the earliest national cotton textile industry organization in China. The establishment of this trade organization has played a good role in coordinating internal production and coping with external difficulties for Chinese mills. It can be said that the Chinese Cotton Mill Owner's Association not only played an important role in modern Shanghai but also in the economic and social development of modern China. At the same time, the establishment of Chinese Cotton Mill Owner's Association is of great significance for the establishment of information system of modern Chinese textile industry.

\section{The Constitution of Chinese Cotton Mill Owner's Association and the establishment of Cotton Information System}

The articles of association of Chinese Cotton Mill Owner's Association 1917 states that in the early stage of its establishment, the Chinese Cotton Mill Owner's Association will provide the industry with cotton and gauze market situation and professional investigation as its mission. This is one of the main purposes of the establishment of the Chinese Cotton Mill Owner's Association. It is the most basic and core part of the modern textile industry information system established by the Chinese Cotton Mill Owner's Association. Cotton yarn market was the key to the development of China's cotton mills at that time. At that time, China's cotton mills seldom traded cotton futures business, repurchased and hoarded a large number of cotton, and left a reserve for cotton price changes. Therefore, the demand for cotton and gauze information is very urgent, and timely access to cotton and gauze information is the key to improve the profits of yarn factories.

There are seven articles of organizational responsibility in the articles of association of Chinese Cotton Mill 
Owner's Association in1917, four of which are more than half of the work content about cotton and gauze information service, two of which are the key contents of " support each other " during the construction of the association, and the remaining one is about employment training. In the articles of association, the information about cotton and gauze is as follows: "in case of any major problem or unexpected danger in cotton and gauze market, we shall make detailed discussion and maintain our efforts; in case of any unexpected change in cotton and gauze market and the harvest of cotton in India and the United States, we shall inform our members in advance; we shall investigate the quality of the daily printed yarn, the place of sale and the amount of the printed yarn, as well as the various market conditions and other businesses in China . The above activities shall be reported to the members from time to time by the ordering industry. When the economy of the association is sufficient, the members' reports shall be solicited again. A monthly magazine of the yarn industry shall be published with details of the domestic and foreign cotton and gauze business."

Clearly put forward for the gauze market change survey statistics, but the raw material of cotton survey did not focus on mention. Among the four items of "the purpose of the association" deleted in the filing process of the articles of association in 1917, although it was mentioned that "the government should investigate the production of cotton and the actual amount of cotton needed year by year, and at any time request the government to restrict the export of cotton at its discretion", it was not the "ordinary duty" in the articles of association, but the long-term goal of "yearning for". In the official regulations, ordinary posts only proposed to investigate the cotton production in India and the United States, but did not mention to comprehensively investigate the domestic cotton production.

In 1920, the articles of association of Chinese Cotton Mill Owner's Association expanded in many aspects, but there are still three of the six listed posts about information services. According to the articles of association, "investigate the situation of domestic cotton production and supply and demand and send specialists to visit the Indian and American cotton cities, and report to all factories for reference at any time." The investigation of domestic cotton production was made clear, and the system of investigating and feedback overseas cotton market by specialists was established. At the same time, it is proposed that "the selected and translated works of Chinese and foreign textile academics and celebrities should be contributed to the benefit of the joint promotion of each factory in the conference at any time." China Cotton Journal will also introduce the publication of relevant Chinese and foreign textile academic and famous works on the back cover.

In the articles of association of 1929, the classification of conference affairs was clearer. There were four active conference affairs, two of which were about the services of industry information, namely, "investigating the domestic and foreign markets, reporting the situation of supply and demand; compiling various statistics, publishing textile times." It also puts forward the investigation of Chinese and foreign markets, but pays more attention to the foreign market. According to the survey articles published in newspapers and magazines, Japanese market is the most concerned foreign market of Chinese mills. The statistics are not limited to the single aspect of the cotton and gauze market, including the cotton production at home and abroad, the number of Chinese mills, the trademark of Chinese mills, the situation of skilled workers and many other aspects related to the textile industry.

In 1929, the articles of association clearly defined "publishing textile News" as a common meeting business. From "a monthly yarn magazine, which details the domestic and foreign gauze business situation" to "editing the magazine, now it takes three months as a time, named China Cotton Journal "and then" publishing textile News ", the modern textile industry information system established by Chinese Cotton Mill Owner's Association has gradually evolved and improved. The Chinese Cotton Mill Owner's Association strives to establish an industry information sharing platform, one of the daily work focuses is also industry information service, providing effective and accurate yarn information for Chinese mills, and achieving the purpose of common resistance to raw materials and market risks. From the change of the constitution of Chinese Cotton Mill Owner's Association, we can see the process of the information system of modern textile industry from germination to maturity. In fact, the information system established by Chinese Cotton Mill Owner's Association is indeed a process of gradual normalization and normalization from planning to practice.

After the establishment of the Chinese Cotton Mill Owner's Association, it has held many meetings with Chinese mills to discuss the provision of industry surveys and information on the market situation of cotton and gauze at home and abroad. On April 7, 1918, the Chinese Cotton Mill Owner's Association discussed such issues as "overseas cotton market news" and "translation of a kind of East-West textile daily, which was published in various factories". On April 21, the board of directors decided to "jointly run by the association and the Cotton Industry Federation, first discuss with the American cotton import and export Institute, ask it to telegram on every month and pay a certain amount of money every month, and then discuss it after it is sure." On October 6 
and 27, the board of directors discussed the situation of American cotton market. The cotton exchange replied that it could not directly report to the market, and Weir Company, a member of the exchange, reported the spot market price of American cotton day by day. Each word is worth one yuan and twenty-two cents, about three words a day, and about two thousand yuan a year. The meeting was decided to be jointly organized with the Cotton Industry Federation. When the electricity arrived, the Chinese Cotton Mill Owner's Association informed the Cotton Industry Federation to send people to open it together, and the two sessions paid six months' electricity charge in advance, so as to connect the electricity as soon as possible.

\section{The Establishment and Development of American Cotton Information System}

Between 1912 and 1930, 54.1\% of China's imported cotton come from India, 21.8\% from the United States, 21.7\% from Japan. "Japan was a non-cotton producing country, so most of the cotton transferred from Japan to China was cotton from other countries, and most of the cotton transferred from Japan to China under the guise of Japan, especially the cotton imported from India into China through Japan." However, from 1912 to 1930, the import of cotton from the United States to China was a growing trend. By 1929, the import of cotton from the United States to China accounted for $32.18 \%$. With the increasing demand of Chinese mills for American cotton with better quality, it is particularly important to obtain the market situation of American cotton.

Shanghai's annual import of foreign cotton accounts for four fifths of the country's import of foreign cotton. Different from the purchase of domestic cotton, cotton mills purchase domestic cotton in the form of spot goods, while the purchase of American cotton can only be carried out in the form of futures, and most of them are handled by foreign firms. At that time, there were more than 40 foreign companies dealing with the import of Japanese and American cotton, among which Japan had the largest number, mainly including Toyo Menkwa Kaisha, Nippon Menkwa Kabushiki Kaisha and Gosho Kabushiki Kaisha. These businesses basically controlled the cotton imports of China and Japan at that time. It is difficult for Chinese mills to compete with these businesses if they do not know the cotton market in the United States. Thus, the spot market price information of American cotton is particularly important for Chinese mills.

However, it was only six months since American cotton telegram was put into effect. Due to the interruption of the Pacific telegram line, Europe and the United States telegrams were all slow. At the annual conference on March 23, 1919, some members thought that it was too late to get to Shanghai, but it was useless to use. They advocated to stop and demanded a referendum at the conference. The Secretary of the Chinese Cotton Mill owner's Association reported that the Cotton Federation had sent a letter to stop American cotton telegram. Later, "Wentai Xue proposed, so please change the futures market price to prepare for comparison with the Japanese sooner or later." "After two months of trial operation, the Pacific sea line has been interrupted again and again, and the news is still difficult to be rapid." On May 18, the board of directors discussed the issue of American cotton telegram, which was suspended by public deliberation. American cotton telegram is "calculated to remit a total of US $\$ 800$ to the cotton Federation. As of the end of the year, according to the future account, there is still US\$111.95. Half of the balance has now been allocated to the cotton Federation. "Chinese Cotton Mill Owner's Association came out to buy American cotton telegram to invest in the same industry, reflecting the market information demand of modern national industries such as Chinese mills. It not only focuses on domestic market information, but also overseas market information. At the same time, the same trade organizations pay great attention to the actual effect of market information collection and hold a very pragmatic attitude. On the other hand, at this time, Japan has established a good sharing mechanism in cotton industry information, which can quickly and effectively grasp cotton industry information. Therefore, Chinese mills are eager to obtain accurate international cotton information and establish their own cotton information sharing mechanism, so as to resist all aspects of risks in the operation of mills.

American cotton telegram is the first attempt of Chinese Cotton Mill Owner's Association to acquire and share industry information. Although it was ultimately stopped due to information efficiency problems, it provides experience for later Chinese Cotton Mill Owner's Association to establish newspapers and magazines for the purpose of information exchange. "Overseas Cotton Market News" and "Excerpt and Translation of East and West Textile Daily, a kind of publication in various factories" have always been one of the main contents of information acquisition and exchange of Chinese Cotton Mill Owner's Association, and also provided basic editing ideas for the later edition and publication of China Cotton Journal and Textile News.

The stop of American cotton telegraph did not make the Chinese Cotton Mill Owner's Association give up the investigation of American cotton market, but changed the investigation method and expanded the investigation scope of cotton market. The main investigation methods changed from daily report on American cotton market by Will Company to the investigation on Indian American cotton market by Chinese Cotton Mill Owner's 
Association. With the development of Chinese Cotton Mill Owner's Association, there are many ways to obtain market consultation on cotton industry. The cotton market investigation results of the US Department of Commerce, the United Nations Textile Federation and other institutions will be in line with Chinese Cotton Mill Owner's Associations shared and translated into Chinese by Chinese Cotton Mill Owner's Association. The scope of the survey has changed from the US cotton market survey to the market survey of the world's major cotton producing areas. The cotton market survey report has also become one of the columns of China Cotton Journal and Textile News. It is not a single form of telegram to transmit relevant market information, and the communication efficiency and scope have been enhanced.

\section{References}

Minutes of the Chinese Cotton Mill Owner's Association (1927-1928). Shanghai Municipal Archives, File No: S30-1-35.

China Cotton Journal. (1919-1934).

Textile News (1927-1932).

Social Welfare (Tien Tsin) (1920).

Ren Zhong Monthly Magazine (1932).

The Republican Daily News (1920).

Monthly Journal of Tokyo University of Technology Student union in China (1932).

Front line daily (1946).

Ta-Kung-Pao (L'Impartial) (Shanghai) (1948).

\section{Copyrights}

Copyright for this article is retained by the author(s), with first publication rights granted to the journal.

This is an open-access article distributed under the terms and conditions of the Creative Commons Attribution license (http://creativecommons.org/licenses/by/4.0/). 